\title{
EVALUATION OF WHOLE-BODY VIBRATION AT WORKPLACES OF TROLLEYBUS DRIVERS AND PROPHYLACTIC MEASURES
}

\author{
Igor M. Dudnyk, Olena A. Kossenkova-Dudnyk \\ The Gorky Donetsk National Medical University
}

\section{Introduction}

The trolleybus is an ecological, clean mode of transportation used in urban areas. It does not pollute the air, and acoustic pollution within the seliteb zone is also minimal. Therefore these vehicles serve as excellent modes of transportation within populated areas with industrial development. However, there is little information about whether drivers of these vehicles are exposed to whole-body vibration (WBV). One monograph was published 30 years ago ${ }^{5}$, but our knowledge of whole-body vibration (WBV) and ability to measure it has improved since that time. The goal of this study was to evaluate WBV exposure in trolleybus cabins and determine if there is a potential health risk to drivers working long hours. ${ }^{1,2,4,7}$ We found that pathological states in drivers were associated with long hours of operation and intensive exposure to WBV that was above occupational exposure limits (OELs).

This study measured WBV in trolleybus drivers' (at the cabin' floor and seat) to characterize the source of vibration and determine the best ways to protect drivers from WBV exposure during working hours.

\section{Methods}

The vibration acceleration on the trolleybus' floor and driver's seat in cabin was measured simultaneously along three mutually perpendicular directions ( $\mathrm{x}-, \mathrm{y}-\mathrm{and} \mathrm{z}-$ axes). The root-mean-square (rms) value of the vibration was analyzed in one octave bands from 1 to $63 \mathrm{~Hz}$. The measurements were done with Vibropribor Instrument VShV-003M2 (Taganrog, Russian Federation). Data were collected, using a selfadministered questionnaire and actual field measurements according to national and international standards. ${ }^{3,6}$

\section{Results}

WBV was transmitted to the driver during operation and was classified by source of rise for transport vibration (category). Mechanical fluctuations were the result of movement of the vehicle frame and its separate assemblies and elements of design. Spectral analysis of the vibratory magnitudes enabled us to estimate it as a wide belted vibration. The results of the present study demonstrate that trolleybus drivers are exposed to considerable levels of WBV in the cabin. The levels of vibration, acceleration (rms) in the cabins of these vehicles (floor and seat), exceed the OELs of current standards under certain conditions. These conditions are, inconstant driving with accelerations (speeding up and braking), driving at speeds of more than $30 \mathrm{~km} / \mathrm{h}$, the condition of the road surface, different maneuvers, the condition of the trolleybus as result of operating period. There were positive relationships between the levels of acceleration and the speed of driving of all trolleybuses, the condition of the road surface, and period since the vehicle underwent maintenance. Trolleybuses driving interurban routes differed from those servicing urban routes in the speed of driving and the number of stops. Maximum levels of WBV were measured on routes 
where the surface was uneven and the bus was moving at the considerable speed. The exposures exceeded OELs of acceleration, primarily in the z-axis at low and average frequencies (1 to $16 \mathrm{~Hz}$ ). Long working hours and long durations of WVB exposure (up to $80 \%$ of working time) could also serve as a risk factor for inducing injury among drivers; trolleybus drivers can drive for 7.5 to 9 hours in a work day. However, the average time of driving is 5 (urban cycle) to 6.5 hours (interurban cycle) each the day. Thus, the intensity and duration of WBV exposure in drivers are both occupational factors that may affect the risk or drivers developing an injury or disorder. Therefore reducing exposure to these factors may protect drivers from the effects of WBV incurred while driving trolleybuses.

\section{Discussion}

Three approaches can be used to protect trolleybus drivers from WBV. Vibration isolation systems to reduce oscillations generated by the vehicle can be added, driving surfaces can be repaired and maintained, and anti-vibration seats can be installed to reduce driver's exposure to WBV. From our point of view, pneumatic seats with compressors and air chambers should be installed in all trolleybus cabins. Other interventions include adding "floating" floors to the cabins, and reducing the transmission of vibration to drivers through vehicle maintenance.

\section{References}

1. Dudnik I.N. Evaluation of vibration factor in trolleybuses' cabins, determination of ways and choice of means for reduction of transport vibration at driver's workplaces. (2001). Vestn. Hyg. Epid. 5, 29-33 (in Russian with English summary).

2. Dudnyk, I.M., Owcharek, J.S., Ramana, N.V., and Dudnyk, V.I. (2001). Whole-body vibration in trolleybuses' cabins and occupational protection of drivers. $36^{\text {th }}$ UK Group Conference on Human Response to Vibration: Centre for Human Sciences, QinetiQ. Farnborough, UK, 75-85.

3. ISO 2631/1-1985 (E) (1996). International Organization for Standartization. Evaluation of Human Exposure to Whole-body Vibration, Part 1 - General requirements, Mechanical Vibration and Shock, $2^{\text {nd }}$ ed. Geneva, ISO Standard Handbook. 2.

4. Matviyenko, N.T., Dudnik, I.N., Yakovleva, I.G., and Partas, O.V. (1992) Conditions of drivers' labour on urban electrical transport and their influence at functional state of organism. Actual Problems of Hygiene and Ecology of Transport. Il’ichyevsk, 112 (in Russian).

5. Retnyev, V.M. (1979). Labour Hygiene of Drivers at Passenger Urban Transport. Moscow, Meditzina (in Russian).

6. SSS 3.3.6.039-99 (2000). State Sanitary Standards of Occupational Whole-body and Hand-arm Vibration, Part 4 - Methods of measurement of occupational vibration. Kyiv (in Ukrainian).

7. Svidovyi, V.I., Nikitina, V.N., Filimonov, V.N., Yakovleva, I.A., and Lyashko, G.G. (1999). Occupational hygiene and health in trolleybus drivers. Hig. San. 3, 31-33 (in Russian with English summary). 